\title{
Sleep deprivation does not work: Epidemiology, impacts and outcomes of incidental and systematic sleep deprivation in a sample of Palestinian detainees
}

\author{
Mahmud Sehwail*, Pau Pérez-Sales**, Khader Rasras***, Wisam Sehwail****, \\ Alba Guasch*****, Andrea Galan******
}

Guest Editor: Nora Sveaass, PhD

\section{Key points of interest}

- Systematic sleep deprivation is widely used as coercive interrogation method.

- The use of sleep deprivation seems ineffective in terms of gathering useful information whilst generating physical and psychological suffering in the detainees
*) President and Founder of the Treatment and Rehabilitation Center for Victims of Torture (TRC)/ Clinical Psychologist.

E-mail : mahmud.sehwail@trc-pal.org

${ }^{\star \star}$ ) Clinical Director. SiR[a] Center. Madrid. E-mail: pauperez@runbox.com

$\star \star \star$ Executive Director of the Treatment and Rehabilitation Center for Victims of Torture (TRC)/ Clinical Psychologist. E-mail: khader.rasras@trc-pal.org

$\star \star \star \star)$ Research and Documentation Officer at the Treatment and Rehabilitation Center for Victims of Torture (TRC).

E-mail: wisam.sehwail@trc-pal.org

$\star \star \star \star \star)$ Community Action Group (GAC). E-mail: alba.guasch@gmail.com

$\star \star \star \star \star \star \star)$ Community Action Group (GAC) and SiR[a] Center. Madrid.

E-mail: andrea.galan.sta@gmail.com

\begin{abstract}
Background: Sleep deprivation (SD) is a method used in the context of interrogations aimed to obtain submission, information and confessions. Its impact on producing false confessions has been documented. Even information obtained is true, it will be unreliable as it cannot be separated with what has been suggested by interrogators. The use of SD has been documented in the interrogation of detainees in Israel and two patterns can be identified: one incidental due to the conditions of detention set out here as secondary sleep deprivation (SSD), and one systematic, intentional and linked to continued interrogation, set out here as primary sleep deprivation (PSD). This paper aims to study the prevalence of PSD and SSD in a sample of Palestinian detainees, compare its usage before and after the 1999 Israeli Supreme Court judgment, and compare the impacts and outcomes of SD. Method: The study included a sample of 600 ex-detainees who answered questions related to psychological and coercive methods, subjective psychological impact, clinical measures, psychosocial measures, and medical impact. Classification of SD was built taking into consideration the items related to SD and interrogation. Results: Most detainees reported SSD with around
\end{abstract}


$13 \%$ reporting PSD. Prevalence of PSD has been found larger among people over 25 years old who were detained before 1999. Related to the psychological suffering from the overall detention environment including SD, detainees with PSD and SSD reported significantly higher acute and chronic suffering. It has also been found that detainees with PSD reported long term family, social and physical impacts. Regarding the outcome of SD, the number of signed confessions with either true or false statements increases with $\mathrm{SD}$, but in this case, this did not lead neither to a significantly higher number of convictions nor longer sentences. Conclusion: Sleep deprivation in the framework of interrogations seems ineffective.

\section{Introduction}

Sleep regulation, also referred to as sleep adjustment, sleep manipulation or sleep deprivation is a coercive method used in the context of the interrogation of detainees to foster cognitive, emotional and physical exhaustion aimed to obtain submission or compliance, and ultimately information or confessions (Pérez-Sales, 2017; Reynolds \& Banks, 2010; Sveaass, 2008).

There is no universally accepted legal definition of what constitutes sleep deprivation or what is sometimes referred to as 'prolonged' sleep deprivation, although different sentences in international courts have considered that less than 6 hours could amount to ill-treatment or torture, especially if prolonged in time or added to other circumstances ${ }^{1}$. According to medical studies, although there is a slight

1 Differences sentences of the EcHRT, but specially in Sadretdinov v. Russia. variability in individual needs (from 6 to 9 hours for adults, depending on age), an International Consensus agrees that a healthy normal sleep pattern should include a minimum of 7 hours of daily continuous sleep (Hirshkowitz et al., 2015; Ohayon, Carskadon, Guilleminault, \& Vitiello, 2004).

Sleep deprivation impairs memory retrieval (Havekes \& Abel, 2017) and accuracy (Blagrove \& Akehurst, 2000), cognitive functioning (Killgore, 2010; Lim \& Dinges, 2010) and reasoning, emotion recognition (Killgore, Balkin, Yarnell, \& Capaldi, 2017) and emotional reactions (Tempesta et al., 2010), moral judgement (Barnes, Gunia, \& Wagner, 2015; Killgore et al., 2007; Tempesta et al., 2012) and decision taking (McKenna, Dickinson, \& Orff, 2007). Furthermore, sleep deprivation fosters physical pain amplifying its effects (Schrimpf et al., 2015) and increases fear-memory consolidation and post-traumatic stress symptoms (Feng, Becker, Zheng, \& Feng, 2018; Seyffert \& Berofsky-Seyffert, 2015).

Different studies have documented the impact of sleep deprivation in the production of false confessions. Davis and Leo (2012) developed the IBRD model (Interrogation-Related Regulatory Decline) which proposes that a person's self-regulation capacities must remain intact to confront stressful situations like an interrogation. In their experimental model, they found three situations in particular (emotional overload, sleep deprivation and glucose deficiency linked to food and water restrictions) that undermine the capacity to self-regulate, making the person more vulnerable to pressure during interrogation. In their model, coercive interrogation (most frequently, hours of exhaustive questioning with interrogators shifting roles, taking turns and using emotional and cognitive manipulation tactics) leads 
the person to either reveal pieces of information (which may be true but are most likely fabricated) in an attempt to stop the situation, or confess to whatever is demanded of him or her. Even if some of the information provided by detainees may be true, the weakness causes the detainee's memory to be partial and unreliable; merging what might be true with what has been suggested or fabricated, causing inaccurate information.

There is ample documentation on the frequent use of sleep deprivation in the interrogation of detainees in Israel (Ginbar, 2009; Lein, 2007; OMCT, 2019). A study based on the testimonies of 121 Palestinians who were held, some for up to two months, in the Petah Tikva interrogation facility of the Israel Security Agency (ISA) in the first and last quarters of 2009 showed that $13(11 \%)$ of the detainees reported sleep deprivation during interrogation lasting for over 24 hours (Wolfson, 2010). Some detainees were interrogated continuously for a stretch of several days, with only short sleep breaks. The detainees reported that the conditions in both the cell and the interrogation room damaged their ability to sleep, even when sleep was not interrupted (Wolfson, 2010). In a similar study on the conditions in which inmates are held and interrogated, based on affidavits and witness accounts provided by 116 Palestinians held for security reasons and interrogated at the Shikma detention center from August 2013 to March 2014, 28 (24\%) reported prolonged sleep deprivation. $12(10 \%)$ detainees reported being continuously interrogated for more than 24 hours without being allowed to sleep at all, some of them being interrogated for up to 72 hours. One detainee reported one week of continuous interrogation with a maximum of 2 hours of continuous sleep. Eight detainees reported that if they fell asleep during the interrogation, interrogators made sure to wake them by shouting or banging on the table. Fifteen stated that while they were in the cells, guards and interrogators deliberately kept them from sleeping for days on end (Kadman, 2015).

The Al-Mezan Center conducted a study with 107 Palestinians detained in Gaza by the Israeli Security Forces between 1 November 2013 and 31 October 2014. They reported sleep deprivation in 69 (64\%) cases. This was mostly incidental sleep deprivation due to harsh conditions of collective detention (overcrowding, no access to toilet facilities, food and water deprivation, humiliation). Only 6 detainees underwent interrogation ( $\mathrm{Al}$ Mezan Center for Human Rights, 2014).

The interplay between sleep regulation, sleep disruption and sleep deprivation can be better exemplified by the following. A Palestinian human rights organization presented the case of Ahmed Isleem, a 17 year old boy who was interrogated over 5 consecutive days. During the first day he was under night interrogation from $8 \mathrm{PM}$ to $5 \mathrm{AM}$. After 4 hours rest, the interrogation was resumed at $9 \mathrm{AM}$ and lasted until 3 PM. After 1 hour of rest, it was resumed from $4 \mathrm{PM}$ to $4 \mathrm{AM}$. After 8 hours of rest, the interrogation began again from $12 \mathrm{AM}$ to $6 \mathrm{PM}$ and after half an hour rest, from 6.30 PM to $5 \mathrm{AM}$. In brief, the detainee (a) was interrogated most of the time during night hours (b) was allowed to sleep 13.5 hours in 5 days (120 hours); an average of 2.5 hours/day. This was in addition to threats, physical pressure, stress positions, shackling and hunger (Addameer, 2013). Notably, Ahmed was a minor, although interrogated as if he were an adult. This is not the only case in minors. Different reports suggest that sleep 
deprivation through night interrogation is not an uncommon practice with children in detention (MIFTAH, 2012).

In sum, there are two patterns of sleep deprivation described by detainees: one incidental to harsh conditions of detention (overcrowding, heat, hunger, thirst, noise...) that by itself or combined with other elements could amount to cruel or inhuman treatment. We call this incidental or secondary sleep deprivation (SSD). The other is systematic, intentional and linked to continuous and harsh interrogation, which we call primary sleep deprivation (PSD), and that can amount to torture.

The distinction between PSD and SSD is not always absolute. Quite often the person is interrogated continuously (PSD), and when apparently allowed to rest between interrogations, the person is then put under harsh conditions (noise, thirst...) or being interrupted for apparently involuntary or routine reasons (someone inside the cell, checks...) (both considered as SSD). So, in the interplay between PSD and SSD are those situations in which there is no true reparatory sleep during non-interrogation times through the use of elements of the environment (noise, fear production actions, permanent light, hunger and others)

Israel authorities acknowledge that both kinds of sleep deprivation happen. At different times during the last decades since the Landau Commission Report was published, these forms of treatment have been considered an acceptable practice by judiciary ${ }^{2}$ while at other times they have been restricted to certain legal conditions. The use of PSD in coercive interrogations is, nowadays, considered acceptable by the Israeli Supreme Court according to what is defined as a "necessity defense", which is roughly coincident with the so-called "ticking bomb scenario": a detainee has essential information that must be urgently obtained

2 Commission of Inquiry into the Methods of Investigation of the General Security Service Regarding Hostile Terrorist Activity, 1987, [also known as the Landau Commission Report]

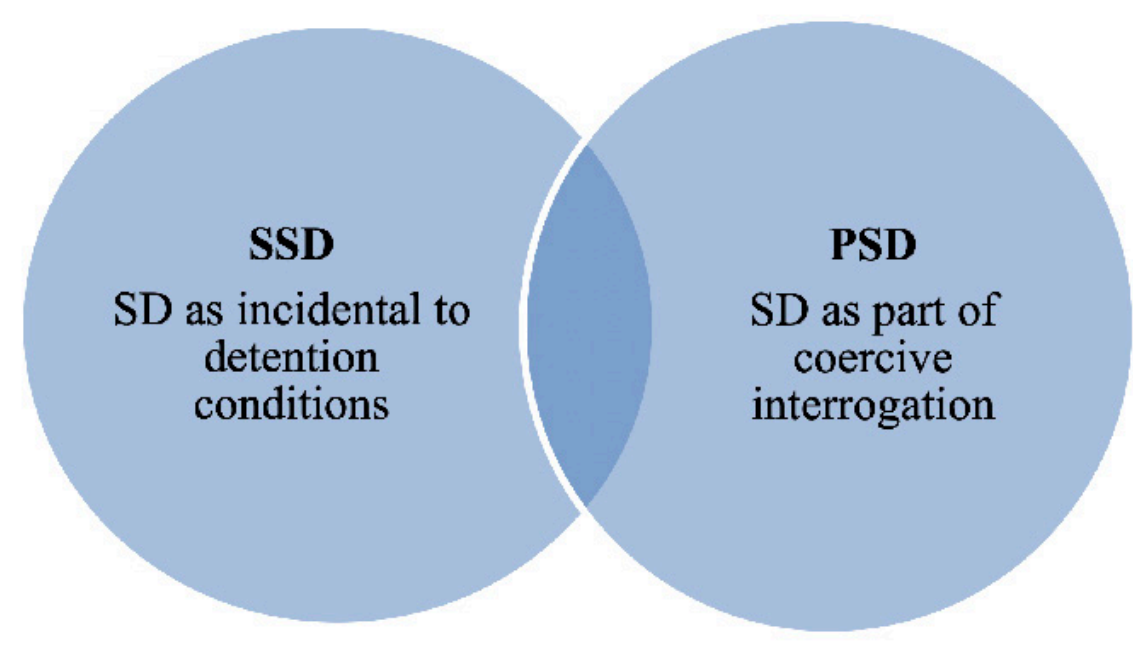


Primary Sleep Deprivation (PSD) - Sleep

Deprivation as part of coercive interrogation
Secondary Sleep Deprivation (SSD) -

Sleep deprivation as incidental to detention conditions
- Intentional

- Complementary to prolonged continuous interrogation

- Creates:

- Mental confusion

- Acute suffering - information or confessions to avoid suffering

- Inability to think and decide clearly

- Potential induction of false memories

- Complementary to accusatory interviewing style - fosters wrong answers - false confessions

to save lives. This position is an attempt to justify torture in certain cases, something which is in clear violation of the nonderogable nature of the prohibition of torture in Article 2 of the UN Convention Against Torture, and which has been criticized by different United Nations bodies, in particular the Committee Against Torture (CAT) in its communications to the Israeli Government ${ }^{3}$. Israeli human rights organizations have also protested this justification. ${ }^{4}$

Knowing that PSD in the framework of coercive interrogation is torture, and in answering a complaint by the Public Committee Against Torture in Israel (PCATI), the authorities stated that sleep deprivation was "not used as interrogation technique" but because "this was necessitated by the gravity of the suspicions

3 Torture Convention/Israel special reportCAT meeting-Summary record. 9 May 1997; Committee against Torture. Concluding observations on the fifth periodic report of Israel. CAT/C/ISR/CO/5. (3 June 2016). See also Special Rapporteur Manfred Nowak (2006).

4 See Efrat Bergman-Sapir (2016). A Veil over Torture: Israel's "Necessity Defense". In http://blog. omct.org/veil-torture-israels-necessity-defense/
- Intentionality cannot be ascertained

- Creates physical and psychological suffering

- Creates physical and emotional exhaustion

- Fosters irritability and breaks solidarity among detainees

- Fosters compliance and submission through tiredness against the complainant and the urgency of obtaining the information he possessed." The authorities consider that sleep deprivation was incidental and a "side effect" of "prolonged interrogation," as opposed to its being imposed "intentionally... for a prolonged period of time, for the purpose of tiring him [the detainee] out or 'breaking him"' (as cited in Ginbar, 2009).

No study to date has explored specifically the use of PSD and SSD among Palestinian prisoners detained and interrogated in Israel in light of its impact. Our study aimed to (a) establish the prevalence of PSD and SSD (primary - systematic sleep deprivation and secondary-incidental sleep deprivation) in a sample of Palestinian detainees (b) compare its use after and before the 1999 Israeli Supreme Court judgment that issued a legal position on the use of certain torture methods by investigative bodies (c) compare the psychological impact of each type of sleep deprivation to a control group of non-SD detainees (d) assess the efficacy of each type of SD from the point of view of the perpetrator in terms of getting signed confessions and convictions.

We hypothesize that the use of primary 
sleep deprivation (intentional and linked to interrogation) as compared to secondary sleep deprivation (incidental to detention conditions) and a control group (detainees that had not been sleep deprived) produces a significant increase in (a) acute suffering (b) long-term sequelae (c) percentage of detainees signing incriminating documents and (d) a higher number of convictions, compared to the effects of SSD (incidental) and a control group. Additionally, that the 1999 sentence significantly diminished but did not eradicate the use of sleep deprivation as part of a potentially torturing environment.

\section{Methods}

\section{Definition of sleep deprivation in the context of detention.}

For the purpose of this study, we define sleep deprivation as not allowing 6 or more hours of continuous rest in a $24 \mathrm{~h}$ period ( $6 / 24$ rule). We define prolonged sleep deprivation as three or more consecutive days of sleep deprivation (6/24 x 3). As previously defined, we distinguish between sleep deprivation that can be intentional (PSD) or incidental (SSD). We define sleep deregulation as breaking a detainee's ordinary sleep schedule reversing the sleep cycles from night to day without necessarily depriving the detainee of sleep.

Sample: We conducted the study from an initial community sample of 600 released exdetainees from 1983 onwards. We calculated a minimum sample size of 400 in order to detect 2-point differences in the instruments used between individuals detained before or after the year 1999, considering a $90 \%$ power and a 2-sided 0.05 alpha level, assuming $\mathrm{SD}=4$. After assessing for missing data, the final sample of the study is 567 ex-detainees.

Participants were contacted through a snowball sampling method in communities all over Palestine, including in Jerusalem, West Bank and Gaza. The ex-detainees, once contacted and agreed on participating, were visited at their own home by psychologists from the Treatment and Rehabilitation Centres for Victims of Torture (TRC) with offices in Jerusalem, Ramallah, Hebron and Jenin.

Measures: The interview lasted between two and three hours and included:

(1) TRC Checklist of psychological and physical coercive methods. A 140-item checklist gathered in 22 categories used in daily clinical work in the TRC center. Each item is ranked on a 4 -item Likertscale: Never happened, Happened once, Happened twice, Happened three or more times. Each of the 22 categories also included a measure of subjective impact with three levels: No or low impact, Mild or severe acute impact (indicating suffering at the moment) and Mild or severe chronic impact (indicating suffering at the moment that lasted for years or even until the moment of the interview).

(2) Clinical measures including:

(a) The Post-Traumatic Stress

Disorder Inventory (PTSDI), a list of symptoms of PTSD that follow DSM-IV Revised criteria, culturally adapted to the Palestinian population, (b) the Arabic version of the Beck Depression inventory and (c) The Arabic version of the Symptom Checklist - 90 (SCL-90-R).

(3) Psychosocial measures including: (a) Family Impact Scale (FIS), a 5-item measure of the impact of detention 
on the role of the detainee in the family (b) Social and Community Impact (SCI), a 5-item measure on the impact of detention on labour and social functioning. All items are dichotomous with an overall score range from 0 to 5 .

(4) Medical impact. A 12-item checklist of medical consequences of torture, with dichotomous answers and values ranging from 0 to 12 .

Sleep deprivation was measured with the Ramallah Sleep Assessment Scale, a 7 -item scale that included 2 questions on PSD and five on SSD according to what detainees described as more prevalent reasons for sleep deprivation (overcrowded cell, frightening acts, gun shots, night snapchecks, freezing room).

The question on sleep deprivation was as follows: Sleep deprivation is defined as not being able to sleep for 6 hours a day. According to this, were you deprived of sleep, in some form of another? (a) This never occurred (b) It happened once (c) It happened twice (c) It happened more than three times. For the purpose of this study, sleep deprivation was considered only when the person informed that it happened at least three or more times during detention.

Interrogation and outcome were measured with the Arabic version of the items: (a) Did you face interrogation around true or false allegations against you? And (b) Did you sign a form or confession whether true or false in its contents? We considered a case as PSD when giving a positive answer to the question on SD and interrogation, and SSD when giving a positive answer only to the question on SD. Thus, some detainees subjected to PSD could also have been subjected to SSD, although detainees who undergo interrogation are usually not merged with other detainees and are kept alone or with another prisoner.

Statistical Analysis: As most variables had nonnormal distributions, we used non-parametric comparison of means (Kruskal-Wallis Test) and cross-tabulation with chi-square statistics for frequencies. All calculations were done using SPSS (23rd version).

Ethical aspects: The Ethical Committee of the TRC Center approved the study. It complied with the ethical standards and procedures for research with human beings of the World Health Organization ${ }^{5}$

5 Standards and operational guidance for ethics review of health-related research with human participants (see https:/www.who.int/ethics/ research/en/) 


\section{Results}

Prevalence of sleep deprivation

Most detainees (59.3\%) reported SSD, $12.9 \%$ PSD and $27.8 \%$ did not declare suffering sleep deprivation (see Figure 1 and Table 1 and 2).

Figure 1: Prevalence of incidental and intentional sleep deprivation

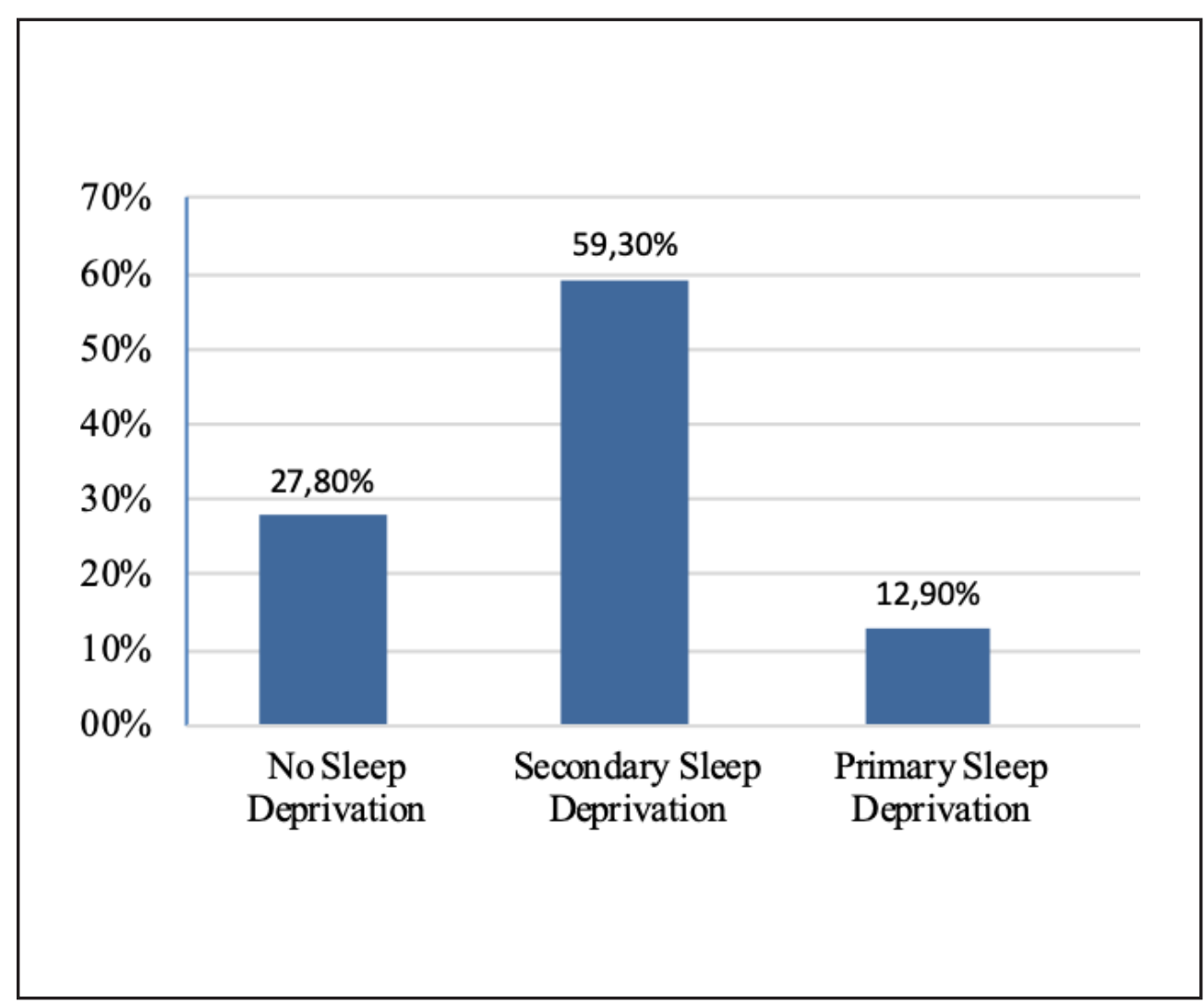

There are no differences between the three groups according to gender, educational level or region (West Bank versus Gaza). However, there is more PSD in people over 25 years of age and in people detained before 1999 (see Table 1). 
Table 1: Epidemiology of sleep deprivation among Palestinian detainees.

\begin{tabular}{|c|c|c|c|c|}
\hline & \multicolumn{4}{|l|}{$\begin{array}{l}\text { Sleep Deprivation } \\
(\mathrm{N}=567)\end{array}$} \\
\hline & $\begin{array}{l}\text { NSD } \\
(\mathrm{N}=158 ; 27.9 \%)\end{array}$ & $\begin{array}{l}\text { SSD } \\
(\mathrm{N}=336 ; 59.3 \%)\end{array}$ & $\begin{array}{l}\text { PSD } \\
(\mathrm{N}=73 ; 12.9 \%)\end{array}$ & $\mathrm{X}^{2}(\mathrm{DF})$ \\
\hline \multicolumn{5}{|l|}{ Gender } \\
\hline Male & $28.5 \%$ & $58.7 \%$ & $12.8 \%$ & \multirow{2}{*}{$1.413(2)$} \\
\hline Female & $24.7 \%$ & $65.8 \%$ & $9.6 \%$ & \\
\hline \multicolumn{5}{|l|}{ Age } \\
\hline$<18$ years & $35.2 \%$ & $56.6 \%$ & $8.2 \% \mathrm{a}$ & \multirow{3}{*}{$18.557(4)^{\star \star \star}$} \\
\hline $18-24$ years & $26.1 \%$ & $63.2 \%$ & $10.7 \%$ & \\
\hline$>25$ years & $21.7 \%$ & $54.8 \%$ & $23.5 \%^{\mathrm{a}}$ & \\
\hline \multicolumn{5}{|l|}{ Educational level } \\
\hline Primary and Secondary & $29.2 \%$ & $54.6 \%$ & $16.2 \%$ & \multirow{3}{*}{$4.081(4)$} \\
\hline Tertiary & $28.2 \%$ & $58.5 \%$ & $13.4 \%$ & \\
\hline Graduate & $25.9 \%$ & $64.6 \%$ & $9.5 \%$ & \\
\hline \multicolumn{5}{|l|}{ Region } \\
\hline West Bank & $26.3 \%$ & $59.6 \%$ & $14.2 \%$ & \multirow{2}{*}{$3.148(2)$} \\
\hline Gaza & $32.5 \%$ & $58.3 \%$ & $9.2 \%$ & \\
\hline \multicolumn{5}{|l|}{ Year of detention } \\
\hline Before 1999 & $20.2 \%$ & $66 \%$ & $13.7 \%$ & \multirow{2}{*}{$13.753(2)^{\star \star \star}$} \\
\hline After 1999 & $34.8 \%$ & $53 \%$ & $12.1 \% \mathrm{a}$ & \\
\hline \multicolumn{5}{|c|}{$\begin{array}{l}\text { NSD: No Sleep Deprivation. SSD: Secondary PSD: Primary; Chi.Square test. }{ }^{\star}=p<.05 ;{ }^{\star \star}=p<.01 \text {; } \\
\star \star \star \\
=\mathrm{p}<.001 . \mathrm{a}=\text { significant difference. }\end{array}$} \\
\hline \multicolumn{2}{|c|}{$\begin{array}{l}\text { Conditions of detention that potentially } \\
\text { foster SSD as reported by detainees } \\
\text { included overcrowded cells }(56 \%) \text {, nightly }\end{array}$} & \multicolumn{3}{|c|}{$\begin{array}{l}\text { snap checks }(70 \%) \text { or being exposed to } \\
\text { disturbing sounds }(48 \%) \text { among others } \\
\text { (see Table } 2) \text {. }\end{array}$} \\
\hline
\end{tabular}

Table 2: Conditions of detention-self declared

\begin{tabular}{ll}
\hline Item & $\%$ \\
\hline Nightly snap-check while you were in the cell & 70.5 \\
Exposed to frightening acts in cell during night & 56.2 \\
Overcrowded prison cell & 54.1 \\
Held in freezing room & 42.7 \\
Food deprivation & 61.7 \\
Water deprivation & 48 \\
Being left in obscurity for long hours & 52.3 \\
Exposed to disturbing, boisterous sounds & 48.2
\end{tabular}


Clinical impact: When assessing the overall environment, including sleep deprivation, $81.9 \%$ and $70.7 \%$ of detainees with PSD or SSD reported acute suffering as compared to $46.5 \%$ in NSD. For a significant $36.1 \%$ and $27.1 \%$, subjective suffering persisted for years (see Table 3). In other words, sleep deprivation per se was a factor that significantly increased overall suffering derived from detention conditions.

Table 3: Subjective psychological suffering derived from overall environment of detention in relation to sleep deprivation

\begin{tabular}{|c|c|c|c|c|}
\hline & \multicolumn{4}{|c|}{ Sleep Deprivation } \\
\hline & NSD & SSD & PSD & $X^{2}(D F)$ \\
\hline Acute PI & $46.5 \%$ & $70.7 \%$ & $81.9 \%$ & $35.47(2) \star \star \star$ \\
\hline Chronic PI & $14.4 \%$ & $27.1 \%$ & $36.1 \%$ & $14.59(2) \star \star$ \\
\hline
\end{tabular}

Table 4 shows clinical measures of long-term sequelae as related to SD conditions. There were no significant impacts in terms of depression and
PTSD. But detainees with PSD that underwent coercive interrogation reported long term family, social and physical impacts.

Table 4: Psychological, physical and social impacts related to sleep deprivation

\begin{tabular}{|c|c|c|c|c|}
\hline & \multicolumn{4}{|l|}{ Sleep Deprivation } \\
\hline & NSD & SSD & PSD & $X^{2}(D F)$ \\
\hline $\begin{array}{l}\text { Depression (Beck) } \\
M(\text { Mean rank) }\end{array}$ & $13.97(274.53)$ & $14.44(283.07)$ & $15.63(300.99)$ & $1.31(1)$ \\
\hline $\begin{array}{l}\text { PTSD (PCLC 4) } \\
M \text { (Mean rank) }\end{array}$ & $35.04(165.70)$ & $39.42(182.60)$ & $43.25(205.78)$ & $4.93(1)$ \\
\hline $\begin{array}{l}\text { Family impact } \\
M \text { (Mean rank) }\end{array}$ & $0.72(252.34)$ & $0.99(286.32)$ & $1.57(330.98)^{\mathrm{a}}$ & $14.65(1)^{\star \star}$ \\
\hline $\begin{array}{l}\text { Social impact } \\
M \text { (Mean rank) }\end{array}$ & $0.76(260.36)$ & $0.91(283.94)$ & $1.43(312.44)^{\mathrm{a}}$ & $6.62(1)^{\star}$ \\
\hline $\begin{array}{l}\text { Physical impact } \\
M \text { (Mean rank) }\end{array}$ & $1.92(217.32)$ & $2.95(292.13)^{\mathrm{a}}$ & $2.81(358.29)^{\mathrm{a}}$ & $43.43(1)^{\star \star}$ \\
\hline
\end{tabular}


Regarding the outcome of sleep deprivation and its relationship with signed confessions (see Table 5), persons who underwent PSD increased from $7.8 \%$ and $6.7 \%$ to $38.4 \%$, which means a fivefold increase $(\mathrm{X} 2: 2, \mathrm{p}<0.000)$. But this does not lead to a significantly higher number of criminal convictions (75 for non-deprived, $79 \%$ for SSD and $80 \%$ for PSD (X2: 6.58 , n.s.). Moreover, the mean time of convictions in months is similar between people with PSD and SSD (28.03 vs 31.89), although higher as compared to non-sleep deprived detainees $(\mathrm{X} 2: 6.89, \mathrm{p}<0.000)$.

Table 5: Comparison of signed confessions, convictions and detention time based on sleep deprivation

\begin{tabular}{lllllll}
\hline & $\begin{array}{l}\text { Signed forms } \\
(\%)\end{array}$ & $X^{2}(D F)$ & $\begin{array}{l}\text { Convicted } \\
(\%)\end{array}$ & $X^{2}(D F)$ & $\begin{array}{l}\text { Time of } \\
\text { conviction } \\
(\text { Mean })\end{array}$ & $F(D F)$ \\
\hline NSD & $7.8 \%$ & & $75.8 \%$ & 18.1 & \\
SSD & $6.7 \%$ & $40.08(2)^{\star \star \star}$ & $79.5 \%$ & $6.58(6)$ & 28.03 & $6.89(2,503)^{\star \star \star}$ \\
PSD & $38.4 \%$ & & $80.3 \%$ & & 31.89 &
\end{tabular}

NOTE: ${ }^{\star}=\mathrm{p}<.05 ;{ }^{\star \star}=\mathrm{p}<.01 ;{ }^{\star \star \star}=\mathrm{p}<.001 . \mathrm{NSD}=$ No sleep deprivation; SSD=Secondary sleep deprivation; $\mathrm{PSD}=$ Primary Sleep deprivation. $1=$ Measured in months.

\section{Discussion}

We have compared the prevalence, the impacts, and the outcome in terms of confessions and convictions in a large sample of 600 former Palestinian detainees who suffered sleep deprivation during detention from 1983 until now. 59\% of detainees report sleep deficiencies resulting from general conditions of detention (table $2)$ : overcrowding of cells ( $54 \%$ ), being exposed to frightening acts (56\%), nightly snap-checks $(70 \%)$, freezing rooms $(42 \%)$, food $(61 \%)$ and water deprivation $(48 \%)$ among others.

These are self-declared conditions of detention and not the result of a monitoring visit inside detention facilities. The results must therefore be considered with caution. Israel has not signed the Optional Protocol of the Convention against Torture, and thus lacks a National Prevention Mechanism (NPM).Monitoring visits are also rare.
Lacking official data and NPM reports, available data depends on retrospective studies from human right groups, sometimes interviewing detainees in prison, but mostly using retrospective interviews after release. The figures reported in our study are slightly higher than other reports (Kadman, 2015; Wolfson, 2010). This cannot be attributed to the conditions of the interview, as the assessment was not done as linked to any forensic or legal process, and thus, the detainees did not have any direct benefit other than participation. There is an urgent need for an independent National Prevention Mechanism that can assess prison conditions and provide uncontested evidence to this issue. Nevertheless, the appalling high figures reported by former detainees leave little doubt regarding the very harsh conditions of detention for the majority of them.

In approximately $13 \%$ of the detainees, there was an intentional use of sleep 
deprivation (PSD) as a mode of coercion in the framework of interrogations. This means that they were not allowed to sleep 6 hours continuously three or more times during interrogation. The study does not have a detailed description of the hours of interrogation of each former detainee because the investigators could not access the official record of the interrogation in the Israel Security Agency files, which is only available to official lawyers under request. Nor was it specifically asked whether, when there was more than one day of sleep deprivation, if the days were consecutive days and whether there was a cumulative effect. So, again, the data requires careful consideration.

The prevalence of PSD and SSD does not change with gender, most likely due to the low level of women under detention and interrogation as compared to men. We would require studies with bigger samples to confirm this. Sleep deprivation is higher among men with older than 25 years of age, most likely coinciding with what can be considered a "high-value detainee".

Sleep deprivation, incidental or intentional, causes high levels of acute suffering and this subjective experience persists for years. However, contrary to what was expected, this does not seem to convert into clinical disorders as measured by depression and posttraumatic stress disorder scales. Interrogation in itself seems to have an impact at the family, social and community levels, with a deterioration of the quality of life and functioning of the former detainee. To our knowledge, there is no data from similar previous studies to which we can compare these results. There are no differences when comparing the use of SD in former detainees from West Bank or Gaza. This will require confirmation with bigger samples including a greater number of detainees from Gaza. Finally, the Israeli Supreme Court judgment of 1999 seems to have had an effect on the use of SD in interrogations. A significant decrease was found, although SD was still used in almost half of the detainees.

From the point of view of interrogators: is sleep deprivation a useful way to obtain information in interrogations conducted under coercion? As expected, PSD (but not SSD) translates into a greater number of detainees signing documents. The number of persons signing a form after PSD increases fivefold, from 6.7 to $38.4 \%$. But, it is important to say, whether the documents that the person signed were true, partly true, fabricated or from induced information is unknown. Obviously, this question was not presented to interviewees due to ethical reasons: to avoid any possibility of putting these persons in danger and risking potentially severe reprisals.

As a proxy measure of the value of these signed forms, we used subsequent conviction rates by a judge and the length of that conviction. Contrary to our hypothesis, this higher number of signed documents does not translate into a higher number of convictions. It is important to say that most detainees (up to $75 \%$ ) were convicted in any case. However the number of additional convictions related to interrogations using $\mathrm{SD}$ is statistically irrelevant. In other words, these forms provide information that most of the times will not be supported in court hearings by any evidence other than self-incrimination. The number of people convicted is extremely high and similar in all three groups.

Therefore, the use of sleep deprivation as a form of coercion in the framework of security interrogations does not provide useful or relevant information that the state needs to indict a detainee. 
Furthermore, if one compares the length of the subsequent sentences, there are no significant differences between the length of the sentence of general prisoners with incidental sleep deprivation and prisoners under tortured interrogation with intentional sleep deprivation. This result enforces the idea that using PSD does not lead to relevant information that changes the severity of the sentences.

\section{Conclusions}

We have studied the impact of sleep deprivation as part of a detention environment and as part of coercive interrogations. Sleep deprivation of 6 hours or less causes severe acute psychological distress. It does not appear to cause serious clinical sequelae per se in the long term, although it has family, community and social consequences. This pain and suffering does not result in information or confessions that lead to a greater number of convictions or longer sentences. In other words, sleep deprivation does not work. Possibly the false information generated by the victim's attempt to avoid and interrupt the suffering associated with sleep deprivation will cause many of the statements obtained to be fabricated or false and thus generate an unnecessary effort of verification. Primary sleep deprivation in the framework of interrogations seems not only inhumane but largely ineffective from the point of view of those who impose it on detainees. Even if effective in obtaining information it should be totally prohibited in Israeli law, but in this case the necessity argument claimed by the Israeli Supreme Court to justify its use, cannot even be sustained from a scientific point of view. SD is not only ethically wrong: our data also suggests that it simply does not function.

\section{References}

Addameer. (2013). Palestinian political prisoners in Israeli prisons. Retrieved from http://www. europarl.europa.eu/meetdocs/2009_2014/ documents/dplc/dv/palestinianpoliticalprisoners/ palestinianpoliticalprisonersen.pdf

Al Mezan Center for Human Rights. (2014). Torture and cruel, inhuman and degrading treatment: the Palestinian population, the Gaza Strip and Israeli Authorities. Retrieved from https://www.mezan. org/en/uploads/files/14519781991754.pdf.

Barnes, C. M., Gunia, B. C., \& Wagner, D. T. (2015). Sleep and moral awareness. Fournal of Sleep Research, 24(2), 181-188. https://doi.org/10.1111/ jsr. 12231

Blagrove, M., \& Akehurst, L. (2000). Effects of sleep loss on confidence-accuracy relationships for reasoning and eyewitness memory. Fournal of Experimental Psychology: Applied, 6(1), 59-73. https://doi.org/10.1037/1076-898X.6.1.59

Denemark, D. (2009). Trust, Threat and Opposition to Anti-terrorism Police Powers : Australia in Comparative Perspective. (July 2009), 12-16.

Feng, P., Becker, B., Zheng, Y., \& Feng, T. (2018). Sleep deprivation affects fear memory consolidation: Bi-stable amygdala connectivity with insula and ventromedial prefrontal cortex. Social Cognitive and Affective Neuroscience, 13(2), 145-155. https://doi. org/10.1093/scan/nsx 148

Ginbar, Y. (2009). 'Celebrating' a decade of legalised torture in Israel. Essex Human Rights Review, 6, 169-187. Retrieved from http://projects.essex. ac.uk/ehrr/V6N1/Ginbar.pdf

Gronke, P., Rejali, D., Drenguis, D., Hicks, J., Miller, P., \& Nakayama, B. (2010). U.S. Public ppinion on torture, 2001-2009. PS: Political Science E Politics, 43(03), 437-444. https://doi.org/10.1017/ S1049096510000697

Havekes, R., \& Abel, T. (2017). The tired hippocampus: the molecular impact of sleep deprivation on hippocampal function. Current Opinion in Neurobiology, 44(March), 13-19. https://doi.org/10.1016/j.conb.2017.02.005

Hirshkowitz, M., Whiton, K., Albert, S. M., Alessi, C., Bruni, O., DonCarlos, L., ... Adams Hillard, P. J. (2015). National sleep foundation's: Sleep time duration recommendations: methodology and results summary. Sleep Health, 1(1), 40-43. https://doi.org/10.1016/j.sleh.2014.12.010

Homant, R. J., Witkowski, M. J., \& Howell, M. (2008). Is torture ever justified? College students' attitudes toward coercion/torture. The fournal of the Institute of Fustice $\mathcal{E}$ International Studies, 8, 152-165. 
Kadman, N. (2015). Backed by the System : Abuse and Torture at the Shikma Interrogation Facility. B'Tselem \& HaMoked Center. Retrieved from https://www.btselem.org/sites/default/ files2/201512_backed_by_the_system_eng.pdf

Killgore, W. D. S. (2010). Effects of sleep deprivation on cognition. In Progress in Brain Research (Vol. 185). https://doi.org/10.1016/B978-0-444-537027.00007-5

Killgore, W. D. S., Balkin, T. J., Yarnell, A. M., \& Capaldi, V. F. (2017). Sleep deprivation impairs recognition of specific emotions. Neurobiology of Sleep and Circadian Rhythms, 3(February), 10-16. https://doi.org/10.1016/j.nbscr.2017.01.001

Killgore, W. D. S., Killgore, D. B., Day, L. M., Li, C., Kamimori, G. H., \& Balkin, T. J. (2007). The effects of 53 hours of sleep deprivation on moral judgment. Sleep, 30(3), 345-352. https://doi. org/10.1093/sleep/30.3.345

Lein, Y. (2007). Absolute prohibition: The torture and ill-treatment of palestinian detainees. B'Tselem \& HaMoked. Retrieved from: https:// www.btselem.org/download/200705_utterly_ forbidden_eng.pdf

Lim, J., \& Dinges, D. F. (2010). A meta-analysis of the impact of short-term sleep deprivation on cognitive variables. Psychological Bulletin, 136(3), 375-389. https://doi.org/10.1037/a0018883

McKenna, B. S., Dickinson, D. L., \& Orff, H. J. (2007). The effects of one night of sleep deprivation on known-risk and ambiguous-risk decisions. F Sleep Research, 16, 245-252.

MIFTAH. (2012). Palestinian Prisoners. Fact Sheet. (Vol. 1229).

Miller, P. (2011). Torture Approval in Comparative Perspective. Human Rights Review, 12(4), 441463. https://doi.org/10.1007/s12142-011-0190-2

Nowak, M. (2006). What Practices Constitute Torture? US and UN Standards. Human Rights Quarterly, 28(4), 809-841. https://doi. org $/ 10.1353 / \mathrm{hrq} .2006 .0050$

Ohayon, M. M., Carskadon, M. A., Guilleminault, C., \& Vitiello, M. V. (2004). Meta-analysis of quantitative sleep parameters from childhood to old age in healthy individuals: developing normative sleep values across the human lifespan. Sleep, 27(7), 1255-1273. Retrieved from http:// www.ncbi.nlm.nih.gov/pubmed/15586779

OMCT. (2019, March, 21). It's now (even more) official: torture is legal in Israel. OMCT. Retrieved from http://blog.omct.org/its-now-even-moreofficial-torture-is-legal-in-israel/

Pérez-Sales, P. (2017). Psychological torture: Definition, evaluation and measurement. In Psychological Torture: Definition,
Evaluation and Measurement. https://doi. org/10.4324/9781315616940

Reynolds, A. C., \& Banks, S. (2010). Total sleep deprivation, chronic sleep restriction and sleep disruption. In Progress in Brain Research, 185, 91103. https://doi.org/10.1016/B978-0-444-537027.00006-3

Schrimpf, M., Liegl, G., Boeckle, M., Leitner, A., Geisler, P., \& Pieh, C. (2015). The effect of sleep deprivation on pain perception in healthy subjects: A meta-analysis. Sleep Medicine, 16(11), 1313-1320. https://doi.org/10.1016/j. sleep.2015.07.022

Seyffert, M. \& Berofsky-Seyffert, A. (2015). Waking up to the forensic and ethics risks of systematic sleep deprivation. The fournal of the American Academy of Psychiatry and Law. 43, 132-6.

Sveaass, N. (2008). Destroying minds: Psychological pain and the crime of torture. CUNY Law Review, 11(2), 303. https://doi.org/10.31641/ clr110210

Tempesta, D., Couyoumdjian, A., Curcio, G., Moroni, F., Marzano, C., De Gennaro, L., \& Ferrara, M. (2010). Lack of sleep affects the evaluation of emotional stimuli. Brain Research Bulletin, 82(1-2), 104-108. https:/doi. org/10.1016/j.brainresbull.2010.01.014

Tempesta, D., Couyoumdjian, A., Moroni, F., Marzano, C., De Gennaro, L., \& Ferrara, M. (2012). The impact of one night of sleep deprivation on moral judgments. Social Neuroscience, 7(3), 292-300. https://doi.org/10.10 $80 / 17470919.2011 .614002$

Thomas, N. K. (2011). On turning a blind eye and a deaf ear: society's response to the use of torture. International fournal of Group Psychotherapy, 61, 6-25. https://doi.org/10.1521/ijgp.2011.61.1.6

Washington Post. (2004). Bush and Iraq. Washington Post-ABC News Poll. Retrieved from http:// www.washingtonpost.com/wp-srv/politics/polls/ trend_052304_q27_31.html

Wolfson, Y. (2010). Kept in the dark. Treatment of Palestinian detainees in the Petah Tikva interrogation facility of the Israel Security Agency. https://doi. org/10.1016/S0961-1290(06)71719-7 